\title{
"The messenger is the place of a man's judgment«: Diplomacy between Emperors and Caliphs in the Tenth Century
}

\author{
Courtney Luckhardt*
}

Travel and communication in the early medieval period were fundamental parts of people's conceptions about temporal and spiritual power, which in turn demonstrated a ruler's legitimacy. Examining the role of messengers and diplomatic envoys between the first Umayyad caliph of al-Andalus, 'Abd al-Rahman III, and his fellow tenth-century rulers in Christian kingdoms, including the Byzantine emperor Constantine VII Porphyrogennetos and the first Holy Roman emperor, Otto I, illuminates internal and external negotiations that defined the pluralistic Iberian society in the early Middle Ages. Formal religious and ethnic differences among Muslim rulers and non-Muslim messengers enhanced the articulation of political legitimacy by the caliph. Diplomatic correspondence with foreign rulers using the multiplicity of talents and ethno-religious identities of their subjects was part of the social order provided by the Andalusi rulers and produced by those they ruled, demonstrating the political authority of the Umayyad caliphate.

Keywords: diplomacy, messengers, al-Andalus, political authority, 'Abd al-Rahman III, Muslim-Christian relations

»The wise sages have said... the messenger is the place of a man's judgment, and his letter is the place of his intellect."

So related Ibn al-Farra' in the Rasul al-muluk, a treatise on diplomacy commissioned by the caliph of al-Andalus in the second half of the tenth century. ${ }^{1}$ Political and diplomatic connections between elite groups and proto-states happened at the personal and individual level in the early medieval period. At the same time, travel and communication were fundamental parts of people's conceptions about temporal and spiritual power. Messengers traversed the Mediterranean bearing letters and gifts between the rulers of many regions, each with their own habits, cultures, and faiths. The messenger was a political or religious elite himself, carefully chosen to bear the words of his patron despite the hardships of travel and the potential dangers of transgressing foreign customs. The envoy was not merely a delivery service; his performance, oral and physical, was a substitute for face-to-face interaction

\footnotetext{
* Correspondence details: Courtney Luckhardt, Assistant Professor, Department of History, University of Southern Mississippi, 118 College Dr. \#5047, Hattiesburg, MS 39406 USA, Email: courtney.luckhardt@usm.edu

1 Ibn al-Farra', Rasul al-muluk, Ch. 7, trans. Vaiou, 69.
} 
between the parties. ${ }^{2}$ Cross-cultural connections occurred across political and geographical borders, with messengers traveling long distances to demonstrate the power and articulate the political legitimacy of their patrons.

Within the diverse society of al-Andalus, Muslim rulers utilized their Jewish and Christian subjects as messengers to non-Muslim kingdoms. The medieval messenger was chosen by his ruler for his ability to relate the words, ideas, and policies of his master to foreign rulers. Unlike most tenth-century Christian and Muslim polities, Muslim leaders in al-Andalus ruled an ethnically mixed population, which included Visigoths, Hispano-Romans, Berbers, Jews, Slavs, Arabs, and others. They might be dhimma (Christians or Jews), 'ajam (Romancespeakers), muwalladūn (indigenous Muslim converts), or they or family members might have been included in multiple categories. ${ }^{3}$ The Muslim Andalusi caliphs did not choose nonMuslim messengers out of any commitment to convivencia, a concept which reflects the late twentieth-century ideal of multiculturalism rather than the lived experiences of medieval Andalusis. ${ }^{4}$ Indeed, much of what has been called Andalusi »toleration « was in fact the willingness of the Arab rulers to employ non-Muslims and non-Arabs in their court, which at times provoked a backlash among the elite Muslim intelligentsia. ${ }^{5}$ The Andalusi rulers also did not choose non-Muslim messengers out of a materialist conception of realpolitik, privileging security and power over confessional ties. ${ }^{6}$ Likewise, medieval rulers were not attempting to build a foundation for the modern state. ${ }^{7}$

In the case of diplomatic relations with foreign rulers, it was precisely the confessional divisions between Andalusi rulers and their Christian and Jewish courtiers and diplomats that made the latter able negotiators on behalf of their Muslim rulers. The choice of an effective messenger showed the judgement of a ruler in seeking out a man who would both represent the interests of the ruler and present them effectively to an opposing power. In the cause of choosing judiciously, the religious ties and religious divisions that played a significant role in the internal politics of the Andalusi caliphate were an important factor. In their multiconfessional realm, ethno-religious groups interacted and communicated on intimate levels while at the same time maintaining their cultural distinctions within formal frameworks of exclusion, a "paradox of plurality. ${ }^{8}$ However, these internal religious divisions did not shape rulers' understanding of where their international interests lay, nor overtly determine who

Camargo, Special Delivery 173-189.

Safran, Defining Boundaries in al-Andalus, 57-58.

4 The post-war era shaped convivencia, from Castro, España en su Historia to Menocal, The Ornament of the World. See also Szpiech, The Convivencia wars.

5 Collins, Caliphs and Kings, 174.

6 This has been the interpretation of the role of religion in the rrealist strand of International Relations (IR) theory, see Snyder, Introduction, 7-14. IR theory has neglected the role of religion in global affairs and none of the three major strands (realism, liberalism, constructivism) takes religion much into account.

7 Previous focus has been on the medieval origins of modern political systems using teleological approaches, see Strayer, On the Medieval Origins and Bain, The medieval contribution, 1-26. Others have argued that seeking to understand modernity through medieval analogy leads to profound misunderstandings of both, see Holsinger, Neomedievalism and Freedman and Spiegel, Medievalisms Old and New, 677-704. 
their external friends and enemies might be. In the diplomatic realm, religion's influence was not principally felt though its role in shaping individual identity, self-perception, or worldview. ${ }^{9}$ Andalusi Muslim rulers used non-Muslim messengers and courtiers to serve their own practical diplomatic ends with Christian states, with Andalusi Christian, Muslim, and Jewish individuals and collectives at times acting in a manner that appeared inconsistent with their religious ideals or identity.

To establish their legitimacy and authority, the Muslim rulers of al-Andalus needed standards for their diplomatic proxies. From this milieu, a treatise on Andalusi diplomacy, the Rasul al-muluk, was written by Ibn al-Farra.. ${ }^{10}$ The Rasul al-muluk is part of the Muslim tradition of $a d a b$, or advice, literature, also present throughout the Latin West as the specula principum, or "mirrors for princes", genre. ${ }^{11}$ In this case, Ibn al-Farra's advice on diplomacy was intended for Andalusi Muslim rulers, but it also functioned as a kind of "mirror for messengers", with some passages addressed to messengers and diplomats themselves. ${ }^{12}$ The ostensible goal of the treatise was to establish diplomatic standards compatible with Qur'anic ethics.

The treatise, along with well-known accounts of the Andalusi exchanges and embassies with non-Muslim states in the late tenth century, demonstrates the role of messengers in illuminating the political and religious relationships that shaped Andalusi society. This is best seen in practice by examining the cross-cultural diplomatic interactions of the Umayyad caliph of Cordoba, 'Abd al-Rahman III (r. 912-961). ${ }^{13}$ 'Abd al-Rahman consolidated power and adopted the title of caliph in 929 after he had taken over smaller kingdoms around Cordoba. The early tenth-century decline of the Abbasid caliphate in Baghdad and the rise of the Fatimid dynasty in Ifriqiya provided a catalyst for the declaration of an Umayyad caliphate in Spain. By 950, 'Abd al-Rahman's caliphal state with its capital at Cordoba was stable and prosperous, promoting intellectual and cultural ties from Baghdad and Tunis to Constantinople and Metz. 'Abd al-Rahman maintained diplomatic relations with other Muslim elites, from Berber chieftains to Fatimid caliphs, using Muslim messengers. However, it is his embassies with Christian rulers that are some of the most famous accounts of early medieval diplomacy, including relations with the Christian rulers immediately to the north in Iberia and Provence, as well as the Byzantine emperor Constantine VII Porphyrogennetos (r. 945959), and the first Holy Roman emperor, Otto I (r. 936-973). Examining these episodes and the messengers involved in light of the Rasul al-muluk will demonstrate the way that formal religious and ethnic differences among rulers and messengers enhanced the articulation of political legitimacy by the caliph. 
The selection of appropriate messengers and diplomats was seen as a demonstration of Andalusi rulers' judgement and wisdom, justifying their claims to political authority in the Iberian Peninsula. Umayyad authority in the region was grounded in Arab patriarchal dynastic claims, even though they were descended matrilineally from non-Arabs. ${ }^{14}$ However, just as important as these dynastic claims was the justification of their rule through their success in governing the Iberian peninsula. ${ }^{15}$ This "performance legitimacy - the ability to get things done - is part of relational political authority, defined as a social contract between a ruler, who provides a social order that is valuable to those they rule, and the ruled, who comply with the ruler's commands necessary to the production of that order. ${ }^{16}$ The idea that successful rule depended on the satisfaction of one's subjects was a truism in tenth-century al-Andalus; good policy included "winning the hearts of the common people by being fair to them. ${ }^{17}$ Diplomatic exchanges with foreign rulers using the multiplicity of talents and ethno-religious identities of their subjects was part of the social order provided by the Andalusi rulers and produced by those they ruled, which legitimized the political authority of the new Umayyad caliphate in the Iberian Peninsula.

\section{The Problem of Piracy in the Western Mediterranean}

Cross-cultural connections between al-Andalus and the neighboring kingdoms in the western Mediterranean occurred across physical borders, but also across the imagined borders of religion and ethnicity. The most famous diplomat of tenth-century al-Andalus was undoubtedly Hasdai ibn Shaprut, a Jewish courtier at the caliph's court at Cordoba. ${ }^{18} \mathrm{Ibn}$ Shaprut was a physician, administrator, and ambassador - a grand wazir. He traveled to the Christian regions of Leon and Catalonia on the caliph's behalf, communicated with the Jews of Narbonne in Francia, corresponded with Jewish converts, the Khazars, in Central Asia, and served as the caliph's chief negotiator with the Holy Roman emperor's messenger to Cordoba in the 950s. Hasdai ibn Shaprut was unique; as a key advisor for both caliphs 'Abd al-Rahman III and his successor, Caliph al-Hakam II, it was likely Ibn Shaprut who commissioned the Rasul al-muluk under the aegis of one of the two caliphs, based upon his experience as both messenger and courtier. ${ }^{19}$ Ibn Shaprut was a talented diplomat who used his Jewish identity in service of the Muslim Andalusi rulers, producing social order for himself and his confessional community, while at the same time legitimating the political authority of the Umayyad caliphate. In the pluralistic Andalusi society, Jewish messengers made convenient go-betweens for Muslim and Christian rulers, as they were excluded from religious cohesion with the majority group, but served the political needs of the caliphate, who in turn provided legal protection.

Ruggles, Mothers of Hybrid Dynasty, 69-70.

Safran, The Second Umayyad Caliphate, 119. Safran analyzes Umayyad strategies, especially the creation of monumental architecture (such as the Madinat al-Zahra) and sponsorship of historians.

Lake, Relational Authority and Legitimacy in International Relations, 331-332.

Ibn 'Abd Rabbih, 'Iqd Al-Farid, Ch. 1. trans. Boullata, 17. Safran, The Second Umayyad Caliphate, 9-10.

Hasdai ibn Shaprut is known from a variety of Arabic, Judeo-Arabic, and Hebrew sources and has been the subject of extensive scholarship. See Golb, The Caliph's Favorite, and most recently, Decter, Before Caliphs and Kings, 4-6.

Vaiou, Diplomacy in the Early Islamic World, 24. 
Hasdai ibn Shaprut first appears in the sources as part of the embassies between the caliph of Cordoba and his neighbors regarding piracy on the Mediterranean. Peace treaties between 'Abd al-Rahman III and Christian rulers of northern Iberia and southern Francia in the 940s indicated that some pirates were Andalusi. While the pirates along the Provençal and Catalan coasts were not under the direct control of the government in Cordoba, they were in contact with the caliph's messengers and were likely indirectly supported by the Andalusi navy based in Almería and the Balearic Islands. ${ }^{20}$ The messengers represented the legitimate power of the caliphate. At the same time, the reason for the diplomatic mission was the actions of non-state actors loosely connected with the Andalusi government.

In the ninth century, groups of Andalusi Muslim pirates, including some based at Fraxinetum in the hills above modern St-Tropez, harassed Christian ships based in southern France and northern Italy. ${ }^{21}$ Additionally, Iberians in both Muslim and Christian territories increased their fortifications and naval fleets due to Viking incursions in the Mediterranean. The evidence from the surviving textual sources and material culture is problematic in both dating and context, as the new walls, towers, and docks that dotted the coastal landscape seem to have come from a period without textually documented Viking raiding in the late ninth century. ${ }^{22}$ These improved defenses might have been responsible for the limited attacks in the period, but there is no evidence that the fortifications were used to defend against Scandinavians, rather than pirates from the Balearics or the Maghreb, whom the written sources also mention. The increase in the Andalusi navy and their coastal fortifications, whether to protect against Viking or Maghrebi pirates, began in the ninth century, which allowed alAndalus's maritime dominance in the western Mediterranean to continue through the tenth century.

The embassies between 'Abd al-Rahman and rulers in the western Mediterranean were not focused on common defense of Iberia and other Mediterranean ports from Scandinavian pirates, but rather on the actions of Andalusi Muslim pirates. It is unlikely that these nonstate actors were even under the nominal control of al-Andalus given the lack of political hegemony by any state in the pre-modern western Mediterranean. However, pirates operating in the territories of non-centralized medieval governments, such as Francia, often engaged in time-intensive kidnappings for ransom. In contrast, those operating around more centralized states, such as al-Andalus, often seized ships and cargo and sold them for profit because there were markets necessary for operations there. ${ }^{23}$ This is borne out in the 972 kidnapping of Abbot Maiolus of Cluny, who was one of many hundreds, perhaps even thousands, of Christians who were captured in Alpine passes by the Muslims of Fraxinetum. ${ }^{24}$ In contrast, material culture tells a different story about the pirates of Fraxinetum's relationship

20 Al-Uhri, Tarsi al-akbar, 31 and Jorge Lirola Delgado, El poder naval de Al-Andalus.

21 Ballan, Fraxinetum: An Islamic Frontier State, 23-76.

22 Christys, Vikings in the South, 65-66.

23 Hastings, Geographies of state failure, 213. Though focused on modern examples and using terms anachronistic to the medieval period, Hastings' conclusion that pirates in sfailed states (read: non-centralized medieval governments) engage in kidnappings for ransom, while those in weak states (read: more centralized states) with stronger infrastructure more often seize and sell goods.

24 Bruce, Cluny and the Muslims of La Garde-Freinet, 39. 
with the Andalusi state. Four tenth-century Muslim shipwrecks have been excavated along the Provençal coastline since the $1960{ }^{25}$ The wreck at Batéguier, off the coast near Cannes, lies on a dangerous reef at a depth of approximately 200 feet. However, the reef does not seem to have been responsible for the wreck; the intact hull indicates that a naval battle or a fire was responsible. Likewise, the wreck at Agay (approximately 20 miles down the coast from Cannes) was likely also caused by a naval attack based on the presence of a contemporary second vessel lying at right angles to the west, as well as a fragment of hull lying isolated a few hundred meters from the main site. ${ }^{26}$ All four sites contain assemblages of distinctive Andalusi pottery, as well as millstones and oil lamps. These ships were under attack, perhaps from pirates from Fraxinetum, though we cannot know for certain.

Christian elites of Septimania and Catalonia were concerned about protecting their merchant ships. The Andalusi Muslim chronicler Ibn Hayyan (987-1076) discussed embassies between al-Andalus and the Christian kingdoms of the north in volume five of his ten-volume work on Iberian history, Kitab al-Muqtabis. ${ }^{27}$ Volume five breaks off in 941, and the following volume does not survive. In his account, a noble called Unjuh (unknown from other sources), had his domain in the territory of Arles at the mouth of the Rhône. He »sent a delegation to the city [of Barcelona] to observe for him, and he asked for a guarantee of safety for the various kinds of merchants of his land [traveling] to al-Andalus, and that was agreed upon. ${ }^{28}$ The protection agreement included safe passage for any Christian merchant from Unjuh's territory who recognized the caliph's authority regarding their ships' property and their own lives while sailing the western Mediterranean. The peace agreements and the guarantees for Christian merchants' safety were "conveyed to Nasir ibn Ahmad, the Muslim commander at Fraxinetum, and to the governors of the Eastern Islands [Balearics] and of all the coastal ports of the land of al-Andalus. $\aleph^{29}$ The safe-passage agreements did not apply to all Christian ships, merely those who had paid appropriate obeisance to the caliph's authority. These cross-cultural connections occurred across borders, with the messengers and the agreements they negotiated demonstrating the power and legitimacy of their patrons.

In 940, 'Abd al-Rahman's Jewish counselor Hasdai ibn Shaprut negotiated a treaty between the caliphate and the Christian count of Barcelona. The issue of safety in western Mediterranean waters was integral to his negotiations with Barcelona and other Christian kingdoms. Ibn Shaprut's confessional division between both his Muslim patron and his Christian opponents in Barcelona allowed him to serve his ruler and appear to be less partisan in the negotiations. Ibn Hayyan described the embassy and peace treaty negotiated by Hasdai ibn Shaprut in 940 with Sunyer, count of Barcelona, who had fought Muslim border lords, taking Tarragona and Tortosa in 936 and 937. These victories provoked both a military and diplomatic response from Cordoba. Ibn Shaprut was sent to Barcelona in the early spring

25 Joncheray, Four Saracen Shipwrecks, 100-107 and Hermanns, Vestigios altomedievales procedentes, 251-260.

26 Joncheray, Four Saracen Shipwrecks, 103a.

27 Ibn Hayyan, Al-Muqtabis V, ed. Chalmeta et al.; trans. Viguera and Corriente; trans. Cobb.

28 Ibn Hayyan, Al-Muqtabis V, § 308, trans. Cobb, 85.

29 Ibn Hayyan, Al-Muqtabis V, § 308, trans. Cobb, 85 . 
of 940. He had the backing of the Muslim navy, who followed him that summer, leaving the Andalusi naval base at Almería on 11 May 940, arriving in Barcelona on 19 July 940 during Ibn Shaprut's embassy. ${ }^{30}$ The threat of military action was clear and Count Sunyer capitulated, making peace with 'Abd al-Rahman under duress. As Ibn Hayyan stated »informed [the navy] about the peace with Sunyer, lord [of Barcelona] and he made them refrain from making war on him, and the navy departed from the port of Barcelona right away. « $^{31}$ By 950, 'Abd al-Rahman had firm control of the frontier territories of Lleida and Tortosa again. ${ }^{32}$

Having made his threats with the Andalusi navy at his back, Ibn Shaprut returned to Cordoba. He brought with him Gotmar, Sunyer of Barcelona's envoy, to finalize the treaty. In return for Sunyer's capitulation, the caliph ordered the navy to practice "abstinence from [Sunyer's] provinces and peaceful behavior towards the people of his land « for two years. ${ }^{33}$ Such peace applied only to Barcelona, and only for two years. It did not prevent the Andalusi navy (or Muslim pirates) from continuing to raid in the area. 'Abd al-Rahman's created a treaty that worked against the interests of his co-religionist pirates, who had demonstrated a threat to wider trade relations with nearby regions. However, his confessional differences with his Christian neighbors made the negotiations delicate. Utilizing the talents and the outsider/insider status of his Jewish envoy, 'Abd al-Rahman and Hasdai ibn Shaprut together produced social order in the peninsula, which in turn legitimized the political authority of the Umayyad caliphate both within and outside its territory.

At least one Christian ruler in the western Mediterranean imitated the policy of the caliphs of Cordoba of legitimating their rule by using the formal religious and ethnic differences among rulers and messengers. Viscountess Richildis of Narbonne negotiated her own peace and trade agreement with 'Abd al-Rahman. ${ }^{34}$ She sent gifts and her Jewish advisor, a man named Bernat, to the court at Cordoba. Narbonne, as part of the territory of Septimania, had been part of al-Andalus for forty years, between 719 and 759, and there was a vibrant Jewish community there. ${ }^{35}$ Culturally connected to al-Andalus, though now with Christian elite political governance, Richildis utilized her Jewish subjects as messengers in diplomatic negotiations. 'Abd al-Rahman »entertained [Richildis'] messenger bountifully« though Ibn Hayyan does not state their exact agreement. Richildis and 'Abd al-Rahman, despite their own confessional differences, spoke the same language of diplomacy and used the religious and ethnic differences among the populations inside their territories, both with significant minority populations, each to their own advantage.

30 Ibn Hayyan, Al-Muqtabis $V$, trans. Cobb, 85. Ibn Hayyan gave the precise dates in the Muslim calendar: the last day of Rajab in A.H. 328, and the tenth day of Shawwal A.H. 328.

31 Ibn Hayyan, Al-Muqtabis $V$, trans. Cobb, 85.

32 It is tempting to see this episode as a precursor to the breakup of the caliphate and the establishment of the taifa kingdoms, but such teleology is unhelpful to understanding the real concerns of the early tenth century; Jarrett, Rulers and Ruled, 172.

33 Ibn Hayyan, Al-Muqtabis V, § 309, trans. Cobb, 86.

34 Richildis, wife of Viscount Odo of Narbonne, appears as a witness or presiding over a court of law in a number of documents between 924 and 977. She was also identified as the daughter and only child of Count Wilfrid II Borrell and Countess Garsendis of Barcelona in 936; her uncle was Count Sunyer of Barcelona; Cheyette, Ermengard of Narbonne, Ch. 5, endnote 15, 384.

35 Bachrach, Early Medieval Jewish Policy, 18. 


\section{Relations between Andalusis and Ottonians}

Messengers, no matter their confessional ties, traveled long distances in the early medieval period to demonstrate the power of their patrons, and this was particularly true when establishing the legitimacy of a new dynasty or title, as both the Andalusis were doing in the Iberian peninsula, and their northern neighbors, the Ottonians, were doing in eastern Francia. The initial impetus for the series of embassies initiated between East Francia and al-Andalus between 953 and 956 seems to have been the ongoing concern for piracy and trade in the western Mediterranean. The diplomatic relationship between the two rulers, Otto I and 'Abd al-Rahman III, occurred at a point at which Otto's power base was in transition, as he did not take the title of Holy Roman Emperor until 962, though 'Abd al-Rahman had long since taken the title of caliph in 929 and established himself as the ruling force in Iberia. Their relationship through their proxies is documented principally in two sources. The first is a hagiographical source, the Life of John of Gorze, about Otto's ambassador, whom he sent to Cordoba with gifts and a letter in 953. The vita was written circa 978, only four years after the death of its subject, by a fellow monk, Jean of St-Arnoul. ${ }^{36}$ The final third of the vita describes John of Gorze's trip to Cordoba. 'Abd al-Rahman also sent an ambassador north to Otto's court both before and after the embassy of John of Gorze. The latter was undertaken by a Mozarabic Christian cleric named Recemund, whose time in East Francia is discussed by a different Ottonian diplomat, Liudprand of Cremona, who was sent to Constantinople in 968. Liudprand dedicated his historical narrative Antapodosis (»Retribution") to Recemund and described the actions of the pirates at Fraxinetum. ${ }^{37}$

Beyond the problem of piracy, the other reason given for the diplomatic convoy to the south was that 'Abd al-Rahman had sent his own ambassador to Otto's court previously, with a letter that contained various blasphemies against Christ. ${ }^{38}$ That messenger had died at Otto's court, and Otto, wanting to continue the conversation, and also respond in kind with an offensive letter, sent his own messenger. Otto sent John of Gorze with gifts and a letter with words in it that were offensive to Islam. None of these letters survive; the general content is known through narrative sources. Benjamin Kedar has argued that these letters represent a minor misunderstanding of theological doctrine, the first letter perhaps containing some reference to Islamic tenets that medieval western Christians might find offensive. ${ }^{39}$ Kedar bases his assumption that the letter was not in fact blasphemous on the fact that the caliph's initial letter was brought by a Mozarabic Christian bishop who died of unknown causes while at Otto's court. However, given their minority status in the caliphate, Mozarabic Christians would have had a different cultural standard for statements "offensive" to Christianity than those the Ottonian court would have had. A Christian bishop employed as an ambassador by the caliph would be used to exclusionary, and to an outsider's ear, offensive, statements of religious difference. The initial letter, which touched off two more subsequent embassies, need not have been either blasphemous or misunderstood, but was likely both.

36 Jean of St-Arnoul, Vita Iohannis, ed. Jacobsen.

37 Luidprand of Cremona, Antapodosis I.1-4, 5-7, ed. Chiesa.

38 Jean of St-Arnoul, Vita Iohannis, Ch. 115.2, ed. Jacobsen, 418.

39 Kedar, Religion in Catholic-Muslim Correspondence, 407-421. 
The messenger's role in causing misunderstanding, and indeed willful offense, to the recipients of his master's letter is addressed by Rasul al-muluk. Ibn al-Farra' discussed the situation of a messenger "carrying a harsh message to another ruler, ordered to deliver it exactly as they were told « to highlight how the messenger's desired qualities of loyalty and diplomatic talent are displayed. ${ }^{40}$ The messenger had been tasked with sending an offensive and harsh message to a neighboring king, angering the foreign king and causing him to take out his anger on the bearer of the message by threatening punishment. The messenger replied that he would convey even offensive messages back to his patron, which the king questioned, saying that the messenger would be afraid to report back anything negative. The messenger responded, "It would be strange that I should come to you with his message and be safe from your anger, although I am hostile to you, and then should take your words to him and not trust his patience, although I am with him ... « $^{41}$ This logic and loyalty diffused the king's anger, and the moral of the tale is the truly ancient chestnut that "the messenger is merely the bearer [of a message] and should not be blamed." Part of the utility of messengers who shared the faith of the letters' recipients but not that of their own masters, as was the case for Mozarabic Christian messengers who served the caliph, was the possibility of diffusing volatile situations by the messenger and recipient sharing the ecumenical tie of a common religious faith, but not a political one in that they served different rulers.

The death of the caliph's ambassador while in East Francia, as well as a need to continue the conversation about the Muslim pirates off the Provençal coast, and a desire to reduce the caliph's impiety led Otto I to send his own ambassador, John of Gorze, to Cordoba. John was an ascetic monk of comparatively humble beginnings who traveled in Italy and Lotharingia to reform monasteries to his religious standards at the request of various local authorities. He and other Gorze monks had journeyed to Rome at the request of Pope Agapetus II in order to "restore discipline « to the monastery of St. Paul in 950. The Gorze Reform movement has been discussed in concert with Cluniac and broader Benedictine reform movements of the tenth and eleventh centuries. ${ }^{42}$ While the monks at Gorze observed the Benedictine rule and the strict enclosure of stabilitas loci, John of Gorze traveled on behalf of the monastery for a variety of reasons, practical, political, and scholarly. ${ }^{43}$

Unlike Septimania or al-Andalus, the Ottonian rulers in eastern Francia did not have a significant population that was not part of the majority religion to involve in diplomatic relations, nor did they wish to. John of Gorze was co-opted by Otto I for diplomacy through his bishop, Adalbero of Metz, who was a patron to Gorze. John was known as a holy man; his power came from his exemplary life and behavior, not from his lineage. In the tenth century "era of reform ", the mutually beneficial relationship of holy men and powerful patrons made John not just a mascot for monastic reform and the holy Christian life, but a tool that Otto sought to use in his relationship with Caliph 'Abd al-Rahman III. His strictness in his Christ- 
ian behavior was seen as an asset for the embassy, as he was a Christian of a different stripe from both his less severe local brethren and from Mozarabic clerics. This is the very opposite tack to that taken by 'Abd al-Rahman, and advised by the Rasul al-muluk, who utilized his non-Muslim subjects to smooth diplomatic waters. In contrast, Otto sent his most rigorous cleric, one guaranteed to take a hard line in negotiations.

Additionally, Otto likely sent John of Gorze because he was an experienced long-distance traveler. Religious travel, like pilgrimage or monastic reform, and secular travel, such as that of merchants and diplomats, happened along the same routes, or even in the same people. A merchant could also be a pilgrim; an abbot could also be a diplomat. They all moved along the old Roman roads, on rivers, on the Mediterranean itself, often traveling in boats owned by others, sailed by professionals, buying and selling horses and donkeys, staying in tents, hospitales, and monasteries. The author described John's route, from which the Roman road that John and his entourage traveled on between Metz and Lyon can be inferred. ${ }^{44}$ Having reached Lyon, the party embarked upon a ship down the Rhône and onwards to Barcelona. Upon their arrival in Barcelona, local messengers alerted the caliph that the ambassadors had arrived, and from there men were sent to guide the travelers south, through Tortosa and onwards to the court in Cordoba. Once in Cordoba, the Franks were given accommodations in a villa "fit for a king " only two miles distant from the palace in order to impress these potential allies with the wealth, luxury, and sophistication of the Umayyad court. ${ }^{45}$

On Otto I's orders, John of Gorze arrived in the heart of Muslim Iberia in 953. The vita of John provides a detailed discussion of the embassy, in which the caliph used his non-Muslim subjects in diplomatic negotiations, including Hasdai ibn Shaprut, the caliph's Jewish wazir, and Johannes, a local Mozarabic Christian cleric. The Andalusis were all allies living together, facing the outside force that John represented: the Germanic king Otto I. Despite dogmatic similarities with the envoys for the Christians, these Andalusi individuals were acting collectively based upon these particular circumstances, and not according to an ideal of either unity or chauvinism, but because of the needs of the caliphate and kingdom. These needs included the practical issues of Mediterranean pirates, as well as the not-so-minor skirmish that had erupted over the precise wording of the religious ideas in the diplomatic missives themselves.

The caliph did not meet with John immediately - he sent a trusted advisor to debrief the ambassadors, trying to determine their motivations for the diplomatic mission. The counselor that 'Abd al-Rahman sent first was none other than the experienced ambassador Hasdai ibn Shaprut, whom John of Gorze called "a man of great wisdom and knowledge." Knowing the local customs of both Iberia and Muslims were foreign to John and his entourage, the first thing Ibn Shaprut said to John of Gorze was about how he and his fellow travelers ought to behave in Cordoba.

44 Jean of St-Arnoul, Vita Iohannis, Ch. 117.5, ed. Jacobsen, 424.

45 Anderson, The Islamic Villa, 139. 
These young men should restrain themselves from any possible idle speech or rude gestures; nothing would be so slight that it would not at once be reported to the caliph. If the opportunity for going out was extended to them, they should not practice any offensive humor with the women as there would be a very harsh punishment for them. They should by no means overstep the stipulated boundary, for they would be carefully watched, and if caught, strung up for almost nothing. ${ }^{46}$

The Jewish counselor's admonishments to a Christian cleric-ambassador and his entourage reveal both the cultural divide regarding proper behavior (particularly with women) but also the not so subtle reminder that deviations from proper behavior carried with them severe punishments, even for foreigners. After the lecture on customs, Ibn Shaprut got down to business by asking John of Gorze his purpose in Cordoba and what messages the letter from the emperor contained. John was not shy about the letter's potential for offense. While he was a hardline Christian, John of Gorze was still a skillful negotiator for Otto I as he relayed the letter's disrespectful tone without yet delivering the letter.

After determining that the emperor's letter could not be presented to the caliph, Ibn Shaprut retreated, and a few months later the second of the caliph's non-Muslim subjects arrived to dissuade John from presenting the offensive letter. This time, it was a fellow Christian, a Mozarabic bishop named John. Bishop John made this case to John of Gorze:

Think »under what conditions we live. Through our sins [we are subject to] the authority [of Muslims]. We are forbidden from resisting this power by the word of the Apostle. The only comfort is that, in such a calamity, we are not forbidden from making use of our own laws. If they see diligent observers of Christianity, they protect and embrace them, just as they are pleased by their own association, while they despise the Jews completely.

At this time we advise that, because no harm is being done to religion, we yield to them in other areas and we obey their commands to the extent that they do not hinder our faith. Therefore, it would be much better for you to keep silent about these things now, and to suppress the letter altogether, rather than stir up a very disastrous scandal for you and for your people when it's not necessary to pursue it.«47

With its bias against Jews and Muslims, this Ottonian rhetoric against non-Christians was designed to demonstrate local religious superiority, rather than describe the real conditions of al-Andalus. It is difficult to understand Andalusi diplomatic policy from this source, as it was written by Ottonians (not Andalusis) in a religious genre of literature (hagiography) that was not normally used to bridge the gap between peoples of differing faiths. However, by looking beyond the inflammatory rhetoric and religious chauvinism, the quotation from Bishop John, a Mozarabic bishop, was great advice for how to get along with the Muslim

46 Jean of St-Arnoul, Vita Iohannis, Ch. 121.5-6, ed. Jacobsen, 432.

47 Jean of St-Arnoul, Vita Iohannis, Ch. 122.3-6, ed. Jacobsen, 434-436. Due to damage on some of the upper corners, there are lacunae in the single manuscript, Paris BNF, Latin 13766, ff. 49v-96v. Material in brackets has been inferred from the manuscript context and the critical apparatus in Jacobsen's MGH edition.

48 The embassy occurred about a hundred years after the "martyrs of Cordoba" described by Eulogius in 859 were killed for purposefully blaspheming against Islam, forcing the authorities to kill them. Wolfe, Christian Martyrs and Safran, Identity and Differentiation, 573-598. 
elites. As leaders of a minority religious group, local bishops would have often sought to prevent clashes, especially when the alternative (that is, silence) would harm no one..$^{48}$ As an outsider to al-Andalus and a rigorous monastic reformer, John of Gorze was incensed by this advice, calling Bishop John a coward and then insinuating that the local Christians were not true to the faith because they were circumcised and practiced the same dietary laws as the Muslims by abstaining from pork and other foods. The key difference though between these reactions lies in the power differentials between the parties. John of Gorze was a foreigner and a representative of a powerful ruler in the north. Silence in John's case would have placed him and Otto I in a weaker position. In contrast, the local bishop was a subject of the caliph, and his proposal for silence reveals his subordinate role in the local hierarchy. Mozarabic Christians had a role to play in diplomacy with fellow Christians outside of their political community, such as with the Ottonian envoys. In general, Andalusi ethno-religious groups had a vested interest in working with people with similar political goals, but outside of their respective faiths for practical economic, political, or social purposes.

At this point in the diplomatic exchange, instead of John of Gorze backing down by giving the gifts but not the letter (against the emperor's standing orders), or ruining the whole mission, John and the caliph's intermediaries determined another path, which involved more travel. John of Gorze stayed put as a "guest", or perhaps hostage, of the caliph, and in 955 'Abd al-Rahman III sent a Mozarabic Christian messenger, Recemund, north to Emperor Otto I. Recemund carried a letter from John explaining the situation to Otto, requesting a new letter from his patron that did not contain the offensive passages. Recemund made careful inquiries with John about the customs of the Ottonian court, and traveled north in ten weeks, arriving at Metz in August $955 .{ }^{49}$ He stayed at Metz and Gorze with John's bishop (and Ottonian courtier Adalbero) through the fall and winter, receiving his audience with Otto himself in the spring and returning with a new letter (this one without the offensive passages), as well as a new Ottonian messenger, a cleric from Verdun named Dudo.

Recemund made significant connections among the elite Christians he met at Otto's court, most notably with another diplomat, Luidprand of Cremona, Otto's ambassador to Constantinople on multiple occasions. Liudprand dedicated Antapodosis to Recemund, which he started writing two years after the latter's departure, around 958. Liudprand spent the first four chapters of that work on the dedication to his friend and a discussion of the Muslim pirates at Fraxinetum, which had been the ostensible subject of the whole embassy. According to Liudprand, the connection between the pirates along the Provençal coast and the Andalusis in Iberia was clear, as the Muslim pirates "secretly began to inspect the neighboring populations all around; they sent many messengers to Spain who extolled the place and promised that they considered the neighboring populations to be nothing. ${ }^{50}$ The neighboring populations were likely Christian, and Luidprand assumes they were when he laments the slaughter of Christians in the same chapter. However, this was not necessarily the case, and those Andalusis to whom the pirates sent messengers need not have been Muslim either to

49 Jean of St-Arnoul, Vita Iohannis, Ch. 129.1-3, ed. Jacobsen, 450-452.

50 Luidprand of Cremona, Antapodosis I.3, ed. Chiesa, 6-7. 
see the benefit of raiding their northern neighbors. The relationship between fellow diplomats Luidprand and Recemund, both of whom were Christian, was maintained despite their cultural distinctions and the political agendas of their patrons through formal networks of exclusion, despite their common religious faith. Recemund left East Francia on Palm Sunday (30 March) 956, arriving back in Cordoba in mid-June. At that point, John of Gorze finally received his audience with the caliph, presenting the gifts and the new letter as if the old one had never existed. In reward for his successful handling of the embassy to Otto's court and diffusing the incident, Recemund was made bishop of Elvira, now modern-day Grenada. The social order provided by the Andalusi rulers and produced by those they ruled, such as Recemund, legitimized the political authority of the Umayyad caliphate while at the same time rewarding those who contributed, no matter what their ethnic or religious affiliations.

\section{Andalusi and Byzantine Relations}

The distance between the territories of the Byzantine Empire in the eastern Mediterranean and the Umayyad caliphate in the western Mediterranean was substantial, but both powers sought diplomatic relationships with one another to demonstrate their power and articulate the legitimacy of their rule in their respective spheres of influence. Compared to the Ottonian court, the Byzantine rulers were more familiar with dealing with non-Christians. In general, the Byzantine emperors were on good terms with the Umayyad caliphs of Cordoba during the tenth century, as the latter had stayed out of the naval conflicts between the Byzantines and the Fatimids in the eastern Mediterranean. The Umayyads even took the Byzantine side in some of the skirmishes over Sicily in the 960 s..$^{51}$ Given the cordial, though not warm, relations between the two powers at either end of the Mediterranean, the Rasul al-muluk was careful to suggest that in correspondence with the emperors of Byzantium, there was no need for unnecessary offense in the use of titles. Ibn al-Farra' gave historical examples, first when the tenth Umayyad caliph of Damascus (r. 724-743) corresponded with the Byzantine emperor, addressing the letter, "From Hisham b. 'Abd al-Malik, Commander of the Faithful, to the tyrant, the Byzantine emperor «, causing the emperor to toss out the letter without reading it and "dismember the countries of Islam. ${ }^{52} \mathrm{Ibn}$ al-Farra' clearly saw a connection between poor diplomatic manners and military losses. The Byzantines likewise had a policy of using the appropriate titles in diplomatic correspondence when engaged with Muslim counterparts, and the Rasul al-muluk says that the Byzantine emperor Basil I wrote the Abbasid caliph Al-Mu'tasim utilizing his proper title of Commander of the Faithful and calling him brother. ${ }^{53}$ The use of superlative titles for the caliphs by the emperors was intended to convey respect and acknowledge their authority, as there are many examples throughout the tenth century of such behaviors in diplomatic letters. ${ }^{54}$ Byzantine sources corroborate this,

51 Nu'mān al Maghribi, Kitab al-majalis, 154, 6-8, see Dölger and Müller, Regesten, 1.2, 663b. For Fatimid and Byzantine relations in Sicily, see Davis-Secord, Where Three Worlds Met, 118 and Sutherland, The Mission to Constantinople in $968,57$.

52 Ibn al-Farra', Rasul al-muluk, Ch. 20, trans. Vaiou, 94.

53 Ibn al-Farra', Rasul al-muluk, Ch. 18, trans. Vaiou, 88.

54 Vaiou, Diplomacy in the Early Islamic World, 207-209, note 442. 
including the famous book of Byzantine imperial protocol, De ceremoniis, commissioned by Emperor Constantine VII Porphyrogennetos. In the section on greetings that foreign ambassadors should both give and receive, De ceremoniis instructs imperial ambassadors to the caliph to greet him saying, "Hail, you who rejoice in peace, prudent in councils, both virtuous and very gentle, being in good health and of good cheer, bringing peace from all quarters, very highly distinguished and highly esteemed amermoumnes [commander of the faithful]! Peace to you on land and sea, glory and honor, joy and long life! Most peaceable and nobly-born amermoumnes, may your name be honored and your life long, dearest friend of our holy emperor, admirable and most illustrious amermoumnes! « ${ }^{55}$ Despite the instructions to show respect and friendliness from both Byzantine and Andalusi diplomatic treatises, the Rasul al-muluk was written using historical examples of Muslim diplomacy, many from the period of the conquest of the Levant in the seventh and eighth centuries, with examples of Muslim superiority and Byzantine decline as standard topoi of diplomatic relations.

Between 945 and 949 there were at least two embassies from the Byzantines to Cordoba and likely two embassies of Andalusis to Constantinople..$^{56}$ The Andalusi caliph likely initiated contact, as the earliest source is the De ceremoniis, which speaks of the reception of Andalusi diplomats to Constantinople in 946. The messengers were received in the Great Hall of the Magnaura, a basilica used as a throne room. "Note that when the Spaniards came a reception was held [and] the pergola of Magnaura was not decorated with sendals [silks], but entirely with great skaramangia [ceremonial tunics], and the Phylax's [Palace Treasury's] enameled objects were also hung in it. The reception for the Spaniards was held on October 24 [946]. ${ }^{57}$ Each account of an embassy, whether in Constantinople or Cordoba, included a discussion about how impressed the visiting diplomats were by the palaces and decorations of their hosts. Demonstrating power through wealth and hospitality was a key feature of early medieval political relationships.

The surviving evidence for the Byzantine embassies to Cordoba in Andalusi Arabic sources was not written contemporaneously. The source for these later historians' information on the late tenth century was Ibn Hayyan's eleventh century historical compilation, the Muqtabis. Since the surviving text of Ibn Hayyan's Muqtabis V breaks off in 941, the information on the embassies of the later 940 is delivered through the pens of four later compilers..$^{58}$

55 Constantine VII Porphyrogennetos, De Ceremoniis, II.47, ed. Reiske, 683-684. An uneven English translation is available, Moffat and Tall, Konstantinos Porphyrogennetos.

56 Dating for these diplomatic exchanges is very uncertain. From the perspective of the Andalusi sources, see Codoñer, Bizancio y al-Ándalus, 212-223 and Cardoso, Diplomacy and oriental influence, 106. From the Byzantine perspective, including other embassies in the same period, see Kresten, "Staatsempfänge « im Kaiserpalast, Zuckerman, Le voyage de Olga, and Featherstone, Olga's Visit to Constantinople.

57 Constantine VII Porphyrogennetos, De Ceremoniis, II.15, ed. Reiske, v. 2, 571. See Angelidi, Designing Receptions, 471.

58 Dölger and Müller, Regesten, 1.1.2, n. 651a, n. 657, and n. 659.

59 al-Maqqari, Nafh al-tib, VI.5, trans. Gayganos, v. 2, 140. 
The most extensive extant source is by al-Maqqari, an Ottoman North African historian who wrote his Nafh al-tib in 1628, quoting extensively from the now-lost portions of Ibn Hayyan. Al-Maqqari acknowledged the problematic dating of the embassy explicitly, saying »Which of the ... dates is the right one, God only knows. $^{59}$

Al-Maqqari gave the most expansive account of Byzantine embassy, quoting the lost Ibn Hayyan material at length. He described the decoration of the caliphal palace saying that the "ambassadors were struck with astonishment at the splendor and magnificence displayed before them. ${ }^{60}$ Accompanied by a military escort provided by the caliph, the Byzantine party paraded in strict order of precedence from their residence to the throne room of his palace. The Byzantine envoys were housed at the munya, or villa, of Nasr, which was located on the left bank of the Guadalquivir River within sight of the walled city center of Cordoba itself. ${ }^{61}$ At the palace, 'Abd al-Rahman received them, flanked by his son and heir, al-Hakam, his other sons, as well as his courtiers, also lined up according to their importance. Andalusi historian, Ibn 'Idhari (fl. 1312) made sure to mention that the ambassadors were bowled over by the magnificence of the caliphal palace. ${ }^{62}$ He also indicated that the Byzantine ambassadors were prepared to prostrate themselves before the caliph, but 'Abd al-Rahman gave a signal that they did not need to do so, and the imperial messengers delivered their letter. ${ }^{63}$

According to al-Maqqari, Ibn Hayyan reported that Constantine VII sent his imperial messengers to Cordoba bearing gifts and a ceremonial letter to Cordoba with gold lettering (chrysography) on azure paper requesting an alliance with the caliph. ${ }^{64} \mathrm{He}$ described the missives, saying:

within the letter was an enclosure, the ground of which was also sky-blue, like the first-mentioned, but the characters were of silver; it was likewise written in Greek, and contained a list and description of the presents which the Lord of Constantinople sent to the Caliph. Upon the letter was a seal of gold. Of the weight of four mithkals, on one side of which was a likeness of the Messiah, and, on the other, those of the King Constantine and his son. The letter was enclosed in a bag of silver cloth, over which was a case of gold with a portrait of King Constantine admirably executed on stained glass. All this was enclosed in a case covered with a cloth of silk and gold tissue. On the first line of the 'Inwan or introduction was written, >Constantine and Romanus, believers in the Messiah, Kings of the Greeks', and in the next, >To the great and exalted in dignity and power, as he most deserves, the noble on descent, 'Abd al-Rahman the Caliph, who rules over the Arabs of Andalus. May God prolong his life!'65

The author was clearly impressed with the Byzantine letter on azure parchment with gold and silver lettering, with a seal made of the equivalent of 18.75 grams of gold. While the standard early medieval diplomatic topos is about how awestruck the visitors were by the hosts' magnificence, in this case, the Andalusis were unquestionably impressed by the By-

60 al-Maqqari, Nafh al-tib, VI.5, trans. Gayganos, v. 2, 138.

61 Anderson, The Islamic Villa, 20 and 139.

62 Ibn 'Idhari, Kitab al-bayan, trans. Fagnan, v. 2, 353.

63 Ibn 'Idhari, Kitab al-bayan, trans. Fagnan, v. 2, 353.

64 Ibn 'Idhari, Kitab al-bayan, trans. Fagnan, v. 2, 353.

65 al-Maqqari, Nafh al-tib, VI.5, trans. Gayganos, v. 2, 142. 
zantine emperor's letter, regardless of the message it contained. The Byzantine emperor used chrysography, as well as dyed-purple parchment, exclusively on diplomatic letters in order to impress their foreign recipients, but not on any other kind of imperial privileges or other court documents in the tenth and eleventh centuries. ${ }^{66}$ The Byzantine ambassadors were accompanied by Andalusi messengers upon their return to Constantinople according to alMaqqari, saying that Hisham bin Hudhayl accompanied the Greeks, bearing a magnificent gift with instructions to conclude an alliance. Ibn Khaldun calls the same man Hisham bin Kulayb al-Hayliq, and he was likely the bishop of Cordoba. ${ }^{67}$ Two years later, Hisham returned to Cordoba accompanied again by ambassadors from Constantine VII. Ibn 'Idhari discussed a final Byzantine embassy to Cordoba in 949 with a Mozarabic Christian ambassador. ${ }^{68}$

Despite the regular use of non-Muslim messengers and the reception of both Latin and Greek Christian envoys at court, the religious divisions between the parties were still made clear during these missions. The audience of both the embassy itself and the historical narrative that related it needed reminding of the importance of being not only a subject of the caliph, but also Muslim. Several of the Andalusi histories related how Abd al-Rahman III instructed that a courtier give a welcome speech to the Byzantine envoys that proclaimed the superiority of Islam, the power of the caliphate, the mercy of God, and the humiliation of the enemies of Islam to foreign guests and courtiers alike. ${ }^{69}$ Many scholar-courtiers failed to perform adequately, including a famous scholar from Baghdad, but a Berber scholar and judge named Mundhir ibn Sa'id al-Balluti performed a khutba, or sermon (largely lost), which included: "O Assembly of Muslims! You know here on this peninsula you are surrounded by all kinds of polytheists and all types of heretics who seek to sow dissention among and break your community apart. " ${ }^{70}$ Arabic public sermons and panegyrics to rulers played an important role in the promotion of the caliphate's image. Fundamental to establishing this political legitimacy was the virtue of safeguarding Andalusi territory for the proper observance of Islam against outsiders, and these panegyrics often ended with hopes for the ruler's long life, as it would be through him that the best of all political circumstances were sustained..$^{71}$ The sermon by al-Balluti was meant to demonstrate that the Andalusis were superior to foreigners, even fellow Muslims from the Abbasid caliphate, in oratory, know-

66 Kresten, Chrysographie, 178-179. The recipients of these imperial letters, such as the Ottonian emperors in the tenth century, both competed with and imitated Byzantine authority. The elaborate foreign policy correspondence from the eastern Roman empire was adopted for Germanic privilege certificates, without knowing that imperial privilege documents in Byzantium actually took a quite different form.

67 Codoñer, Bizancio y al-Ándalus, 213. He argues that the name of the Andalusi ambassador should be read as Yatalik, designating him as the highest Christian authority of al-Andalus, which was the bishop of Cordoba.

68 Ibn 'Idhari, Kitab al-bayan, trans. Fagnan, v. 2, 357.

69 al-Maqqari, Nafh al-tib, VI.5, trans. Gayganos, v. 2, 138.

70 Al-Nubahi, Kitab al-marqaba, trans. Marqués, 231-234. Ibn Hayyan discusses al-Balluti's role as a qadi in Al-Muqtabis V, § 329, trans. Viguera and Corriente, 367. See also, Fierro, Mundhir ibn Sa'id al-Balluti, 360-361 and Safran, Defining Boundaries in al-Andalus, 35 and 72-73.

71 Decter, Dominion Built of Praise, 9-10. 
ledge, and performance. It was also meant to indicate that the Umayyad caliphate was equal to the Byzantine Empire. While the use of non-Muslim messengers was one way to smooth the diplomatic waters and enhance the articulation of political legitimacy by Abd al-Rahman III, other methods, including outright statements of superiority over rivals, both Muslim and non-Muslim, were other tools in the Andalusi caliph's arsenal.

\section{Exchanging Messengers, Exchanging Ideas}

In concert with their political roles, the messengers of al-Andalus often served as a conduit through which ideas were transmitted both among themselves and between the scholars of Europe and the Mediterranean. During the initial trip of the Byzantine emperor's men to Cordoba, with the sky-blue letter discussed previously, the Byzantines brought gifts. One account of these gifts is preserved in the life of an Andalusi physician, Ibn Juljul (944-994) written by another physician, Ibn Abi Usayb'iya, circa 1270 in Damascus. ${ }^{72}$ The biography quoted now-lost portions of Ibn Juljul's own work on pharmacology and an autobiographical colophon. ${ }^{73}$ Ibn Juljul was trained by the ubiquitous Jewish physician and wazir Hasdai ibn Shaprut and was the court physician to Caliph Hisham II. The gifts that arrived in Cordoba with the azure letter were a Greek manuscript of Dioscorides' (fl. 50-70) famous pharmacological treatise, De materia medica and a Latin manuscript of Orosius' Historiae adversos paganos. The Byzantine emperor instructed that "Dioscorides' book cannot be utilized except with the help of a person who knows Greek well and is acquainted with the drugs concerned. If there is someone in your country equipped with the necessary knowledge, you will, $\mathrm{O}$ king, derive great profit from the book. As to Orosius' work, you probably have in your country, among the Roman population, some people who read Latin, and if you submit the book to them they will translate it for you into Arabic. $\aleph^{74}$ According to Ibn Juljul, there was no person in al-Andalus whose Greek was good enough to translate the names of the unknown drugs. Following the Byzantine embassy, 'Abd al-Rahman's messenger, Hisham bin Hudhayl, the Mozarabic bishop of Cordoba, went to Constantinople with gifts to the emperor requesting a translator who spoke both Greek and Latin. On the subsequent embassy in 951, Constantine VII sent a Byzantine Christian named Nicholas the Monk to teach Greek in al-Andalus. In his capacity as a physician (rather than a diplomat) Jewish Hasdai ibn Shaprut learned Greek from Nicholas, who »became his favorite and close friend and explained to him those obscure names of drugs." Muslim Ibn Juljul, as a part of the coterie of court physicians, learned from Nicholas as well. Nicholas died in Cordoba during the first year of Caliph al-Hakam II's rule in 961. Ibn Abi Usayb'iya related that, »thanks to the efforts of those persons, it became possible, in Cordoba alone of the whole of al-Andalus, to identify those drugs in a way precluding all doubt, resulting from direct knowledge of the drugs themselves. ${ }^{75}$ The close friendships 
between Christian, Jewish, and Muslim physicians, all working towards the common goal of understanding the obscure pharmacological references of Dioscorides, illustrate the way that individuals of different faiths and political affiliations worked together intimately because of these diplomatic relationships. While in the past this might have been termed convivencia, interactions between different ethno-religious groups were at times positive, negative, and neutral depending on the larger political and religious contexts.

Likewise, John of Gorze's travel to Cordoba and Recemund's travel to East Francia involved the exchange of knowledge, but it also demonstrates the limits of these kinds of cultural interactions. Despite the survival of the eleventh-century library catalog from Gorze Abbey, there do not appear to be any works contained there that scholars can say came definitively from Spain, despite the presumed access of John and his party to books and/or people with scientific knowledge not available in the Frankish world in the tenth century. This is in contrast to books surviving in the catalog from John's trip to Monte Cassino, such as Aristotle's Categories and Boethius' translation of the introduction to Porphyry's Isagoge.$^{76}$ It is certainly likely that scientific knowledge in the Holy Roman Empire was enhanced by this ambassadorial exchange; Recemund is most well-known for his work as a mathematical astronomer and the author of the Calendar of Cordoba, part of the Books of Anwa' genre, common in the Arab world, that provided agricultural, astronomical, and astrological calendrical information. The Calendar of Cordoba was presented to 'Abd al-Rahman III's caliphal successor, al-Hakam II in $961 .^{77}$ Recently, Ann Christys has suggested that the two surviving manuscripts of this source, one in Latin and one in Judeo-Arabic, represent different recensions, and even different authors, that have been conflated into one by modern scholars. ${ }^{78}$ Attributed variously to Bishop Recemund, Bishop Rabi, or Bishop ibn Zaid, conflating them »is to underestimate the prominence of educated Christians in al-Andalus. ${ }^{79}$ Recemund spent a good deal of time at Gorze during his embassy in the north, and the hagiographer Jean of St-Arnoul called him "most orthodox" (adprimae catholicus) in his beliefs and learned in both Latin and Arabic. ${ }^{80}$ John of Gorze's erudition included Easter computus and practical astronomy, important scientific fields in the early Middle Ages. ${ }^{81}$ However, there is no surviving evidence that either John and Recemund brought any astronomical or scientific texts from Cordoba to Gorze, or vice versa.

Diplomatic efforts and correspondence with foreign rulers using the multiplicity of talents and ethno-religious identities of their subjects were part of the social order provided by the Andalusi rulers and produced by those they ruled. If "the messenger is the place of a man's judgment, and his letter is the place of his intellect, " then in the view of Caliph 'Abd

76 Lindberg, The Transmission of Greek and Arabic Learning, 59.

77 Dozy, Le Calendrier de Cordoue, iv and McClusky, Astronomies and Cultures, 166-171.

78 Christys, Christians in al-Andalus, 108-134.

79 Christys, Christians in al-Andalus, 134.

80 Jean of St-Arnoul, Vita Iohannis, Ch. 128.2, ed. Jacobsen, 448.

81 The Easter Controversy of Late Antiquity and the Early Middle Ages, ed. Warntjes and Ó Cróinín, ix. Jean of St-Arnoul, Vita Iohannis, Ch. 18 and 24, ed. Jacabsen, 196 and 210, discusses education using computus. Practical astronomy also included the observation of the sky to find the time of night for the lighting of lamps, in Jean of St-Arnoul, Vita Iohannis, Ch. 80, ed. Jacobsen, 330-334. 
al-Rahman III, the messengers that he sent to Christian rulers and emperors in the mid-tenth century demonstrated his political and religious authority over the ethno-religious communities he ruled in al-Andalus. His wisdom in sending men who shared confessional or ethnic ties with his rivals, but owed their political loyalty to him as al-kalifah al-nasir li-Din Allah (the caliph, the defender of the religion of God) showed his temporal and spiritual power, which in turn demonstrated his legitimacy.

\section{Acknowledgements}

This work was supported by the NEH Mediterranean Seminar and the Lindsey Young Regional Visiting Faculty Fellowship at the Marco Institute for Medieval and Renaissance Studies, University of Tennessee, Knoxville. 


\section{References}

\section{Manuscript}

Paris, Bibliothèque Nationale de France, Latin MS 13766, ff. 49v-96v.

\section{Printed Sources}

Al-Maqqari, Nafh al-tib min ghusn al-Andalus al ratib, ed. Ihsan Abbas (Beirut, 1968); translated from Arabic by Pascual de Gayangos, The history of the Mohammedan dynasties in Spain, v. 2 (London, 1840-1843).

Al-Nubahi, Kitab al-marqaba l-'ulya, ed. Celia del Moral, translated from Arabic by Arsenio Cuellas Marqués, Al-marqaba al-ulya' de al-Nubhi (La atalaya suprema sobre el adiazgo y el muftiazgo) (Grenada, 2005) 231-234.

Al-Uhri, Tarsi al-akbar [Taracea de noticias históricas], ed. and trans. Jorge Lirola Delgado, Almería andalusí y su territorio (Almería, 2005).

Anderson, Glaire D, The Islamic Villa in Early Medieval Iberia, Architecture and Court Culture in Umayyad Córdoba (Farnham, 2013).

Angelidi, Christine, Designing Receptions in the Palace (De Ceremoniis 2.15), in: Alexander Beihammer, Stavroula Constantinou, and Maria Parani (eds.), Court Ceremonies and Rituals of Power in Byzantium and the Medieval Mediterranean, Comparative Perspectives (Leiden, 2013) 465-486.

Bachrach, Bernard S, Early Medieval Jewish Policy in Western Europe (Minneapolis, 1977).

Bain, William. The medieval contribution to modern international relations, in: William Bain (ed.), Medieval Foundations of International Relations (London, 2017) 1-26.

Ballan, Mohammad, Fraxinetum: An Islamic Frontier State in Tenth-Century Provence, Comitatus 41 (2010) 23-76.

Bruce, Scott, Cluny and the Muslims of La Garde-Freinet, Hagiography and the Problem of Islam in Medieval Europe (Ithaca, 2015).

Calvo, Emilia, Ibn Juljul, in: Helaine Selin (ed.), Encyclopaedia of the History of Science, Technology and Medicine in Non-Western Cultures (Dordrecht, 1997) 421.

Camargo, Martin, Special Delivery: Were Medieval Letter Writers Trained in Performance?, in: Mary Carruthers (ed.), Rhetoric Beyond Words: Delight and Persuasion in the Arts of the Middle Ages (Cambridge, 2010) 173-189.

Cardoso, Else, Diplomacy and oriental influence in the court of Cordoba (9th-10th centuries). Unpublished MA thesis (University of Lisbon, 2015). Retrieved on 6 August 2018 from: repositorio.ul.pt/bitstream/10451/18276/1/ulfl183083.pdf

Castro, Americo, España en su Historia (Mexico City, 1948).

Catlos, Brian, Muslims of Medieval Latin Christendom, c. 1050-1614 (Cambridge, 2014).

Cheyette, Frederick, Ermengard of Narbonne and the World of the Troubadours (Ithaca, 2001).

Christys, Ann, Christians in al-Andalus, 711-1000 (London, 2002).

Christys, Ann, Vikings in the South, Voyages to Iberia and the Mediterranean (London, 2015).

Codoñer, Juan Signes, Bizancio y al-Ándalus en los siglos IX y X, in: Inmaculada Pérez Martin and Pedro Bádenas de la Peña (eds.), Bizancio y la Peninsula Ibérica (Madrid, 2004) 212223.

Collins, Roger, Caliphs and Kings, Spain, 796-1031 (Oxford, 2012).

Constantine VII Porphyrogennetos, De ceremoniis aulae byzantinae libri duo, ed. Johann Jakob Reiske (Bonn, 1829). 
Davis-Secord, Sarah, Where Three Worlds Met: Sicily in the Early Medieval Mediterranean (Ithaca, NY, 2017).

Decter, Jonathan P., Dominion Built of Praise, Panegyric and Legitimacy among Jews in the Medieval Mediterranean (Philadelphia, 2018).

Decter, Jonathan P., Before Caliphs and Kings: Jewish Courtiers in Medieval Iberia, in: Jonathan Ray (ed.), The Jew in Medieval Iberia, 1100-150o (Boston, 2012) 1-32.

Delgado, Jorge Lirola, El poder naval de Al-Andalus en la época del califato omeya (Granada, 1993).

Dölger, Franz and Andreas E. Müller, Regesten der Kaiserurkunden des Oströmischen Reiches, von 565-1453. 1. Teil, 2. Halbband, Regesten von 867-1025 (Munich, 2003).

Dozy, R. Le Calendrier de Cordoue de l'année 961. Text arabe et ancienne traduction latine (Leiden, 1873). Nouvelle edition accompagnée d'une traduction française annotée, trans. Charles Pellat (Leiden, 1961).

Featherstone, Michael, Olga's Visit to Constantinople in De Ceremoniis, Revue des Études Byzantines 61 (2003) 241-251.

Fierro, Maribel, 'Abd al-Rahman III: The First Cordoban Caliph (Oxford, 2005).

Fierro, Maribel, Mundhir ibn Sa'id al-Balluti, in: David Thomas and Alex Mallet (eds.), ChristianMuslim Relations: A Bibliographical History, v. 2 (900-1050) (Leiden, 2010) 360-361.

Freedman, Paul and Gabrielle Spiegel, Medievalisms Old and New: The Rediscovery of Alterity in North American Medieval Studies, American Historical Review 103/3 (1998) 677-704.

Golb, Norman, The Caliph's Favorite: New Light from Manuscript Sources on Hasdai ibn Shaprut of Cordova. Lecture presented at the Society for Judaeo-Arabic Studies, Jerusalem, Summer 2009. Retrieved on 14 March 2017 from: oi.uchicago.edu/sites/oi.uchicago.edu/ files/uploads/shared/docs/the_caliph's_favorite.pdf

Handy, Amber, The Specula Principum in Northwestern Europe, A.D. 650-90o: The Evolution of a New Ethical Rule. Unpublished Ph.D. dissertation (University of Notre Dame, 2011).

Hastings, Justin V., Geographies of state failure and sophistication in maritime piracy hijackings, Political Geography 28 (2009) 213-223.

Hermanns, Marcus Heinrich, Vestigios altomedievales procedentes de las aguas de Ibiza/ Eivissa (Islas Baleares) [Evidence of early medieval navigation from the waters surrounding Ibiza (Balearic Islands)], Archivo Español de Arqueología 86 (2013) 251-260.

Holsinger, Bruce, Neomedievalism, Neoconservatism, and the War on Terror (Chicago, 2007).

Hunter, Shireen T, God on Our Side, Religion in International Affairs (London, 2017).

Ibn 'Abd Rabbih, 'Iqd Al-Farid, translated from Arabic by Issa Boullata, The Unique Necklace, v. 1. (Reading, 2006).

Ibn Abi Usayb'iya, Tabaquat al-Atibba, ed. and trans. Lothar Kopf, History of Physicians (Bethesda, 1971). Retrieved on 6 August 2018 from: www.tertullian.org/fathers/ibn_abi_ usaibia_o3.htm\#CHAPTER_XIII

Ibn al-Farra', Rasul al-muluk, translated from Arabic by Maria Vaiou, Diplomacy in the Early Islamic World: a tenth-century treatise on Arab-Byzantine Relations (London, 2013).

Ibn Hayyan, Al-Muqtabis V, ed. Pedro Chalmeta (Madrid, 1979); translated from Arabic by Maria Jesus Viguera and Frederico Corriente, Cronica del Califa 'Abdarrahman III an-Nasir entre los años 912 y 942. (Zaragoza, 1981); ed. Olivia Remie Constable, translated from Arabic by Paul Cobb, Medieval Iberia (2nd edition) (Philadelphia, 2011) 81-86.

Ibn 'Idhari, Kitab al-bayan al-mughrib, translated from Arabic by Edmond Fagnan, Histoire de l'Afrique et de l'Espagne, intitulée Al-Bayano' l-Mogrib, v. 2. (Algiers, 1904).

Jarrett, Jonathan, Rulers and Ruled in Frontier Catalonia, 880-1010 (Woodbridge, 2010). 
Jean of St-Arnoul, Vita Iohannis abbatis Gorziensis, ed. Peter Christian Jacobsen, MGH SRG 81 (Wiesbaden, 2016).

Joncheray, Sean, Four Saracen Shipwrecks of Provence, in: Sean Kingsley (ed.), Barbarian Seas: Late Rome to Islam (London, 2004) 100-107.

Kedar, Benjamin Z, Religion in Catholic-Muslim Correspondence and Treaties, in: Alexander Beihammer, Maria D. Parani and Christopher D. Schabel (eds.), Diplomatics in the eastern Mediterranean 1000-1500. Aspects of Cross-Cultural Communication (Leiden, 2008) 407421.

Kresten, Otto, "Staatsempfänge" im Kaiserplast von Konstantinopel um die Mitte des 10. Jahrhunderts. Beobachtungen zu Kapitel II 15 des sogenannten "Zeremonienbuches" (Vienna, 2000).

Kresten, Otto, Zur Chrysographie in den Auslandsschreiben der byzantinischen Kaiser, Römische Historische Mitteilungen 40 (1998) 139-186.

Lake, David A., Relational Authority and Legitimacy in International Relations, American Behavioral Scientist 53/3 (2009) 331-353.

Lindberg, David C., The Transmission of Greek and Arabic Learning to the West, in: David C. Lindberg (ed.), Science in the Middle Ages (Chicago, 1978) 52-90.

Luidprand of Cremona, Antapodosis, ed. Paolo Chiesa, Corpus Christianorum, Continuatio Mediaevalis 156 (Turnhout, 1998).

MacDaniel, Dennis K, John of Gorze: a Figure in Tenth Century Management, Indiana Social Studies Quarterly 31 (1978) 66-74.

McClusky, Stephen C, Astronomies and Cultures in Early Medieval Europe (Cambridge, 1998).

Menocal, Maria Rosa, The Ornament of the World: How Muslims, Jews, and Christians Created a Culture of Tolerance in Medieval Spain (Boston, 2002).

Moffat, Ann and Maxeme Tall, Konstantinos Porphyrogennetos: The book of ceremonies in two volumes (Canberra, 2012).

Nightingale, John, Monasteries and Patrons in the Gorze reform: Lotharingia c. 850-100o (Oxford, 2001).

Nu'mān al-Maghribī, Kitāb al-majālis wal-musāyarāt, ed. M. Yalaoui (Beirut, 1997).

Ruggles, D. Fairchild, Mothers of Hybrid Dynasty: Race, Genealogy, and Acculturation in al-Andalus, Journal of Medieval and Early Modern Studies 34/1 (2004) 65-94.

Safran, Janina M., Defining Boundaries in al-Andalus. Muslims, Christians, and Jews in Islamic Iberia (Ithaca, 2013).

Safran, Janina M., The Second Umayyad Caliphate. The Articulation of Caliphal Legitimacy in al-Andalus (Cambridge, MA, 2000).

Safran, Janina M., Identity and Differentiation in Ninth-Century al-Andalus, Speculum $76 / 3$ (2001) 573-598.

Snyder, Jack, Introduction, in: Jack Snyder (ed.), Religion and International Relations Theory (New York, 2011) 1-23.

Strayer, Joseph, On the Medieval Origins of the Modern State (Princeton, 1970).

Sutherland, Jon N., The Mission to Constantinople in 968 and Luidprand of Cremona, Traditio 31 (1975) 55-81.

Szpiech, Ryan, The Convivencia wars: Decoding historiography's polemic with philology, in: Suzanne C. Akbari and Karla Mallette (eds.), A Sea of Languages: Rethinking the Arabic Role in Medieval Literary History (Toronto, 2013) 135-161.

Vaiou, Maria, Diplomacy in the Early Islamic World: a tenth-century treatise on Arab-Byzantine Relations (London, 2013). 
Warntjes, Immo and Dáibhí Ó Cróinín (eds.), The Easter Controversy of Late Antiquity and the Early Middle Ages. Its Manuscripts, Texts, and Tables (Turnhout, 2011).

Wolfe, Kenneth Baxter, Christian Martyrs in Muslim Spain (Cambridge, 1988).

Yalaoui, Mohammed, Controverse entre le fatimide al-Mu'izz et l'omeyyade al-Nāṣir, d'après le >Kitāb al-majālis w-al-musāyarāt du cadi Nu'mānı, Cahiers de Tunisie 26 (1978) 7-33.

Zuckerman, Constantin, Le Voyage d'Olga et la première ambassade espagnole à Constantinople en 946, Travaux et Mémoires 13 (Paris, 2000) 647-672.vt 